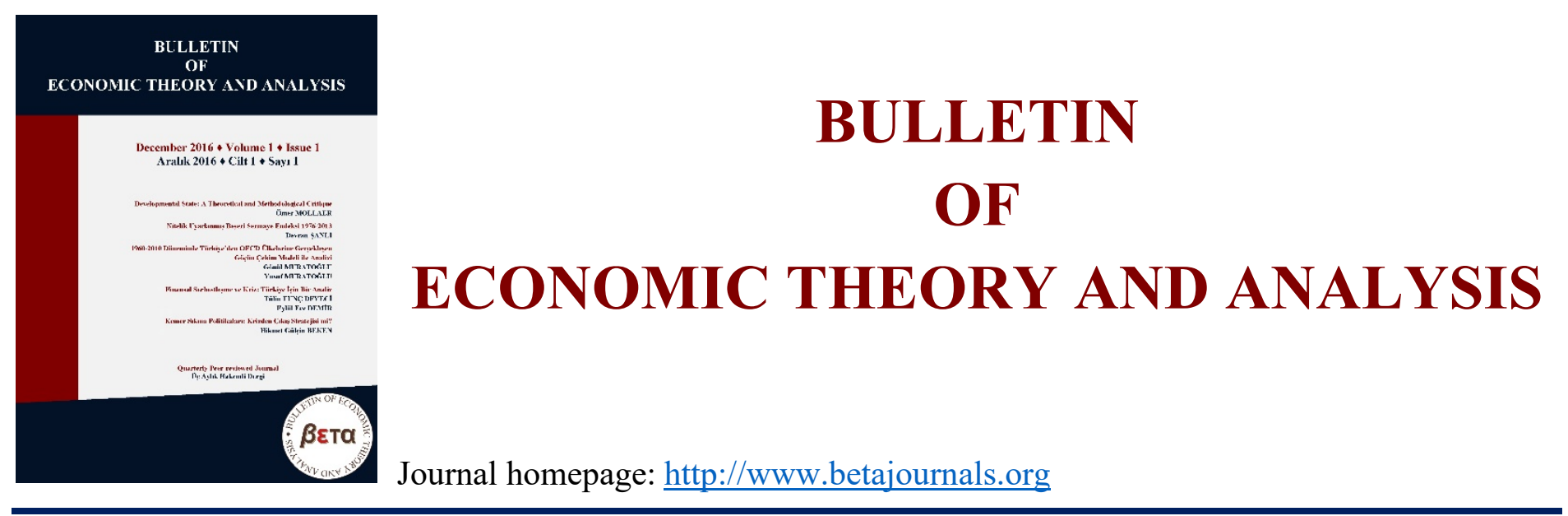

\title{
Döviz Kuru ile Sanayi Üretimi Arasındaki Nedensellik İlişkisi Üzerine Bir Uygulama (2005-2019)
}

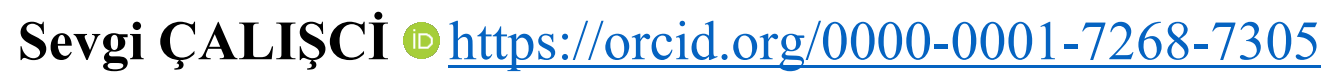

\section{Pelin KARATAY GÖĞÜL @ https://orcid.org/0000-0001-2345-6789}

To cite this article: Çalışci, S. \& Karatay Göğül, P. (2021). Döviz Kuru ile Sanayi Üretimi Arasındaki Nedensellik İlişkisi Üzerine Bir Uygulama (2005-2019). Bulletin of Economic Theory and Analysis, 6(2), 1-25.

Received: 20 Aug 2020

Accepted: 26 Nov 2021

Published online: 31 Dec 2021

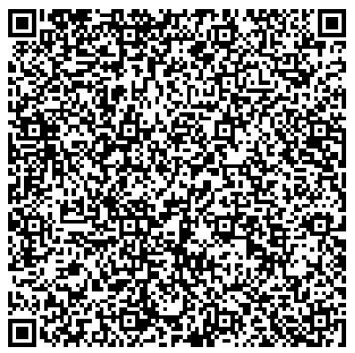




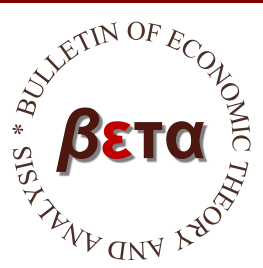

\title{
Bulletin of Economic Theory and Analysis
}

Volume VI, Issue 2, pp. 1-25, 2021

http://www.betajournals.org

Original Article / Araştırma Makalesi

Received / Alınma: 20.08.2020 Accepted / Kabul: 26.11.2021

\section{Döviz Kuru ile Sanayi Üretimi Arasındaki Nedensellik İlişkisi Üzerine Bir Uygulama (2005-2019)*}

\author{
Sevgi ÇALIŞCía \\ Pelin KARATAY GÖĞÜL ${ }^{b}$
}

${ }^{\mathrm{a}}$ Yüksek Lisans Mezunu, Dicle Üniversitesi, İktisat Anabilim Dalı, Diyarbakır, TÜRKIYE

- https://orcid.org/0000-0001-7268-7305

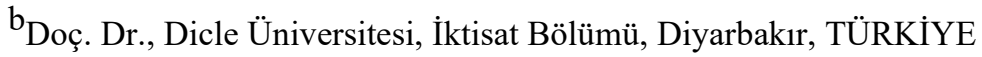

(근 htps://orcid.org/0000-0001-2345-6789

\section{ÖZ}

Küreselleşmeyle beraber ekonomik belirsizliklerin artış gösterdiği bir ortamda döviz kurları, cari hesap ve diğer makro ekonomik değişkenler üzerindeki güçlü etkilerinden dolayı, açık bir ekonomideki en önemli gösterge ve fiyatlar arasında yer almaktadır. Döviz kurları, ülkelerin sanayi sektöründeki üretim miktar ve değerini olumlu veya olumsuz yönde etkilemektedir. Dış ticareti belirleyen pek çok faktör bulunmakla birlikte gerçek hayatta, dış ticareti yapılan malların fiyat (kur) esnekliği en önemli faktördür.

Bu çalışmanın amacı, Türkiye'de 2005-2019 yıllarında döviz kuru ile sanayi üretimi arasında herhangi bir ilişki olup olmadığını ekonometrik bir analizle saptamaktır. Bu amaca yönelik olarak Türkiye'de döviz kuru ile sanayi üretimi ilişkisi, TÜFE Bazlı Reel Efektif Döviz Kuru ve Sanayi Üretim Endeksi, Toplam Sanayi değişkenlerinin 2005:Q1-2019:Q1 dönemleri arasındaki üçer aylık verilerine zaman serisi analizleri uygulanarak incelenmiştir. Değişkenler arasındaki uzun dönem ilişkisi Engle-Granger ve Phillips-Ouliaris eş-bütünleşme testleriyle analiz edilmiş ve Toda-Yomamoto (1995) nedensellik testi yapılmıştır. Eş-bütünleşme testleri sonucunda, döviz kuru ve sanayi üretimi arasında uzun dönem eş-bütünleşme ilişsisi bulunmuştur. Uygulanan nedensellik analizi sonucunda ise, döviz kuru ve sanayi üretimi arasında herhangi bir nedensellik ilişkisi bulunmamıştır.

Anahtar Kelimeler

Döviz Kuru,

Sanayi Üretimi,

Nedensellik

JEL Kodu

E23, F31, C01

İLETiŞiM Sevgi ÇALIŞCİ $₫$ sevgi.calisci@hotmail.com @ aYüksek Lisans Mezunu, Dicle Üniversitesi, İktisat Anabilim Dalı, Diyarbakır, TÜRKIYYE

* Bu çalışma Dicle Üniversitesi Sosyal Bilimler Enstitüsünde Yüksek Lisans tezi olarak Doç.Dr. Pelin Karatay GÖGÜL Danışmanlığında, Sevgi Çalışcı tarafından hazırlanan "Döviz kuru ile sanayi üretimi arasındaki nedensellik ilişkisi: Türkiye üzerine bir uygulama (2005-2019)” başlıklı tezden derlenmiştir. 


\title{
An Application on the Causality Relationship Between Exchange Rate and Industrial Production (2005-2019)
}

\begin{abstract}
Exchange rates are among the most important indicators and prices in an open economy due to their strong effects on current account and other macroeconomic variables in an environment where economic uncertainties increase with globalization. Exchange rates affect the production quantity and value of countries in the industrial sector positively or negatively. Although there are many factors that determine foreign trade, price (exchange) flexibility of foreign trade is the most important factor in real life.

The purpose of this study, with exchange rate of industrial production in Turkey in the years 2005-2019 to determine whether there is any relation to an econometric analysis. For this purpose the relationship between the exchange rate of industrial production in Turkey, CPI Based Real Effective Exchange Rate and the Industrial Production Index, total industry variables 2005: Q1-2019: Q1 between the three-month period were examined by applying the time-series data analysis. Then, long-term relationship between variables was analyzed by Engle-Granger and Phillips-Ouliaris cointegration tests and Toda-Yamamoto (1995) causality test was performed on the variables. As a result of the cointegration tests applied to the variables, long-term cointegration relationship was found between exchange rate and industrial production. As a result of the causality analysis, no relationship was found between exchange rate and industrial production.
\end{abstract}

\author{
Keywords \\ Exchange Rate, \\ Industrial \\ Production, \\ Causality \\ JEL Classification \\ E23, F31, C01
}

\section{Giriş}

Küreselleşme, internet ve teknoloji nedeniyle günümüzde dünya finansal piyasaları entegre ve birbirine bağımlı durumdadır. Bir değişkende meydana gelen tek bir değişiklik dünya çapında domino etkisi yaratır. Bu tür bir riski azaltmak için, belirli bir ülkenin para biriminin iç ve dış değerini dengelemek için para politikaları yapılır. "Ulusal paranın yabancı para cinsinden değeri" olarak tanımlanan döviz kurları geçmişte uluslararası mal ve hizmet alım-satımları cinsinden belirlenmekteydi. Teknolojinin gelişmesiyle birlikte ise kurların ayarlanmasında para piyasaları daha etkin olmuştur. $\mathrm{Bu}$ açıdan küreselleşmeyle beraber ekonomik belirsizliklerin artış gösterdiği bir ortamda döviz kuru, ekonomiye yansıyan en önemli gösterge ve fiyatlardan biri olmuştur.

Uluslararası ticaret, herhangi bir ekonominin gelişmesinde önemli bir rol oynamaktadır. Uluslararası ticarette her ülke farklı para birimi kullandığından dolayı, ticari faaliyette bulunurken ülkelerin kendi kullandıkları para biriminin yabancı ülkelerin kullandığı para birimleri cinsinden değerini bilmeleri gerekmektedir. Yerli ülkenin kullandığı para biriminin yabancı bir ülkenin kullandığı para birimi cinsinden değeri olan döviz kuru aynı zamanda "parite" olarak da 
adlandırılmaktadır. Döviz kurlarındaki değişmeler bir ülkede ticarette bulunan yabancı ülke vatandaşlarının alım gücünü olumlu veya olumsuz bir şekilde etkilemektedir. Sık uluslararası ticaret, dünya finansal piyasasının entegrasyonu, rastgele haberlerin hızlı yayılması, bilgiye kolay erişim, dünya genelinde rekabeti ve belirsizliği artırmıştır. Döviz kuru hareketleri, bir ülkenin dünya pazarındaki rekabet edebilirliğini belirleyen bir araç olarak görülmektedir.

Uluslararası ticarette hükümet belirli amaçları gerçekleştirmek için belirli araçlar kullanarak dış ticarete müdahale etmektedir. Yurt içi endüstrileri koruma, iç fiyat istikrarını sağlama, iç denge, hazine gelirlerini arttırma, vs. amaçlarını gerçekleştirmek için kullanabileceği araçlardan biri de döviz kurlarıdır. Her türlü parasal-finansal hareketlilik, döviz kurları, faiz oranları, yabancı ülkelerin ekonomik durumları ve uluslararası piyasalarda yaşanan ekonomik gelişmeler, ülkelerin sanayi sektöründeki üretim miktar ve değerini olumlu veya olumsuz yönde etkilemektedir.

Ülkeler arasında yapılan karşılıklı ithalat ve ihracat yapan ülkeler birbirlerinin ülke içindeki ekonomik kalkınma hızını etkilemektedirler. Örneğin, dış piyasa talebindeki bir artma yurt içi tesislerde üretimin genişlemesini, işsizliğin azalmasını sağlar. Dış piyasa talebindeki bir azalma ise tam tersi etki yapar. Tesislerde üretimin azalmasına, buna bağlı olarak çalıştırdığı insan gücünü azaltarak işsizliğin artmasına ve böylece ekonomik refahın azalmasına neden olur. Döviz darboğazı gibi ekonomik sebeplerle bazı temel tüketim maddeleri, ara ve yatırım malları ithal edilemezse, ekonomik kalkınma hızı diğer ülkelerin ithalatına bağlı olan ülkelerde ekonomik refahta düşüşler yaşanır ve ulusal ekonomi zarar görür. Türkiye gibi gelişmekte olan ülkeler için döviz kurunun üretim üzerindeki etkisi girdi maliyetlerinin artması noktasında ortay çıkardığı maliyet enflasyonu üzerinden önem kazanmaktadır. Maliyet artışından kaynaklı fiyat artışları üretimin azalmasına yol açmakla birlikte, döviz kurundaki yükselmenin ihracatı arttırıcı etkisine rağmen, fiyatlardaki artışın da ihracatı azaltıcı etkisi söz konusu olabilmektedir.

Bu noktadan hareketle literatüre katkı sağlamak amacıyla bu çalışmada, Türkiye'de döviz kuru ve sanayi üretimi arasındaki ilişki ekonometrik analiz ile test edilmiştir. Döviz kuru ve sanayi üretim arasındaki uzun dönem ilişkisi Engle-Granger ve Phillips-Ouliaris eş-bütünleşme testleriyle analiz edilmiş ve Toda-Yomamoto (1995) nedensellik testi yapılmıştır. Eş-bütünleşme testleri sonucunda, döviz kuru ve sanayi üretimi arasında uzun dönem eş-bütünleşme ilişkisi bulunmuştur. 
Uygulanan nedensellik analizi sonucunda ise, döviz kuru ve sanayi üretimi arasında herhangi bir nedensellik ilişkisi bulunmamıştır.

\section{Literatür}

Berument ve Pasaogulları (2003), Türkiye üzerine yaptıkları çalışmada 1987:I-2001:IV arası dönemi çeyreklik verilerle incelemişlerdir. Granger nedensellik testiyle yapılan analizlerden elde edilen bulgularda, reel döviz kurunun değer kaybetmesinin üretim üzerinde daraltıcı etkilerinin olduğunu ortaya koymuşlardır. Bu noktada, aşırı değerlenmiş ulusal paranın üretim üzerinde anlamlı etkilerinin bulunduğu, finansal kriz riski doğurduğu ve bunun da sonuç olarak, döviz kurunun değer kaybına ve üretimde düşüşlere yol açtığı ifade edilmiştir.

Kasman ve Kasman (2005) çalışmalarında, 1982-2002 dönemi için üçer aylık veriler kullanarak, ihracat arzı üzerinde reel efektif döviz kuruna dayalı olan dış ticaret reformunun etkisini incelemişlerdir. Eş-bütünleşme testi ve Hata Düzeltme modelinin uygulandığı çalışmada, kurdaki dalgalanmanın ihracat üzerinde meydana getirdiği etkinin pozitif yönde olduğuna dikkat çekilmiştir. Analiz sonuçlarında; ihracat, ihracat ağırlıklı reel efektif kur, nispi ihracat fiyatları ve üretim kapasitesi değişkenleri arasında uzun dönem ilişkisine rastlamışlardır.

Choudry (2005) çalışmasında, ABD’nin Japonya ve Kanada'ya yaptığı reel ihracat üzerinde döviz kuru oynaklığının etkilerini 1974-1998 dönemi için incelemiştir. Ampirik çalışmada hem nominal hem de reel döviz kurları kullanılmıştır. Çalışmada, Johansen çok değişkenli eşbütünleşme ve kısıtlı hata düzeltme yöntemi ile kur oynaklığını belirlemek için GARCH modelini kullanmış ve sonuç olarak, reel ihracat üzerinde kurlardaki oynaklığın negatif etkisi bulunmuştur.

Barış1k ve Demircioğlu (2006) çalışmasında, 1980-2001 döneminde Türkiye'de uygulanan döviz kuru rejimi ile ithalat-ihracat ilişkisi incelenmiştir. Çalışma sonucunda, ithalat ve ihracat değişimleri ile reel kur değişimleri arasında uzun dönem ilişkisine rastlanmıştır. Döviz kurundan ithalata güçlü, ihracata ise nispeten güçlü bir ilişki bulunmuşken, ithalat ve ihracatın kur üzerindeki olan etkisinin zayıf olduğu bulunmuştur. Analiz sonucunda ihracat-ithalat ile döviz kuru sistemi arasında kuvvetli olmayan bir ilişkinin olduğu ortaya çıkmıştır. Dış ticareti yönlendirmede konvertibilitenin etkili olmadığı sonucuna ulaşılmıştır.

Gül ve Ekinci (2006) çalışmasında, Türkiye'de reel döviz kurları ile ithalat ve ihracat arasındaki etkileşim, 1990:01-2006:08 dönemine ait aylık verilere zaman serisi analizi uygulanarak 
incelenmiştir. Yapılan Granger nedensellik ve eş-bütünleşme testlerinden elde edilen sonuçlarına göre, reel kurlar ile ithalat ve ihracat arasında eş-bütünleşme ilişkisi bulunmuştur. Aynı zamanda değişkenler arasında var olan nedensellik ilişkisi, ithalat ve ihracattan reel kura doğru tek yönlü olarak bulunmuştur.

Kızıltan ve Cigerlioğlu (2008) çalı̧̧masında, 1982-2005 dönemi üçer aylık verileri kullanılarak Türkiye'de reel döviz kuru, ithalat ve ihracat arasındaki ilişki zaman serisi yöntemi ve koentegrasyon analiziyle araştırılmıştır. Analiz sonuçları, reel döviz kurunun dış ticaret dengesini sağlamada etkin biçimde kullanılamayacağını ve ithalatın kısılması amacıyla alınacak tedbirlerin ihracatı da olumsuz olarak etkileyeceğini göstermektedir.

Aktaş (2010) 1989:1-2008:4 döneminde reel döviz kurları ile ihracat ve ithalat arasındaki ilişkiyi VAR analizi yöntemiyle incelemiştir. Üçer aylık verilerin uygulandığı çalışmada, etki-tepki fonksiyonları ve varyans ayrıştırma uygulaması; dış ticaret dengesi üzerinde reel kurda oluşan bir oynaklığın anlamlı bir etki göstermediği ve dış ticaret dengesini sağlamada reel kurun etkin olarak kullanılamayacağını sonucuna ulaşılmıştır. Aynı zamanda sonuçlar, ithalat üzerindeki kısıtlamaların ihracatı negatif olarak etkileyeceğini göstermiştir. İthalatın, ihracatı önemli ölçüde etkilemesi de ihracatın ithalata ve en önemlisi de ara malı ithalatına bağımlılığın bir göstergesidir. $\mathrm{Bu}$ durum, ithalat ve ihracat değişkenleri arasında güçlü, uzun dönemli ve kalıcı bir ilişkinin var olduğunu göstermektedir.

Yıldırım ve Kesikoğlu (2012) çalışmasında, Türkiye'de ihracat, ithalat ve reel döviz kuru arasındaki nedensellik ilişkisi 2003:1-2011:9 döneminde ampirik olarak araştırılmıştır. Çalışmada kullanılan verilere Hacker ve Hatemi-J (2006) tarafından önerilmiş olan kaldıraçlı bootstrap tekniğiyle düzeltilmiş olan MWALD testi uygulanmıştır. Toplam ithalat-tüketim malı ihracatı, toplam ihracat-ara malı ithalatı, toplam ihracat-toplam ithalat, sermaye malı ithalat1-tüketim malı ihracatı ve toplam ihracat-sermaye malı ithalatı arasında çift yönlü nedensellik ilişkisi olduğu sunucuna ulaşılmıştır. Tüketim malı ihracatından ithalatına ve ara malı ithalatına doğru, toplam ihracattan tüketim malı ithalatına doğru tek yönlü olan bir ilişkiye rastlanmıştır. Döviz kuru ve ihracat ve ithalat arasındaki nedensellik konusundaki tahminlerin tamamında bir nedensellik ilişkisi bulunmamıştır. Bütün olarak değerlendirilen bulgulara göre, ihracat ve ithalat arasındaki bağımlılığın kur politikasını yansız duruma getirdiği ima edilmiştir. 
Cambazoğlu ve Karaalp (2012) çalışmasında, parasal aktarım mekanizması olan döviz kuru kanalının, esnek kur sistemini benimseyen Türkiye'de toplam çıktı ve özellikle de fiyatlar düzeyi üzerindeki etkinliği, 2003:01-2010:08 dönemi için VAR modeliyle sorgulanmıştır. Reel efektif döviz kuru, kısa vadeli faiz oranı, sanayi üretim endeksi, tüketici fiyat endeksi ve net ihracat hacminden oluşan toplam beş makro ekonomik değişken üzerine yapılan uygulama sonucunda; faiz kanalı etkilerini içinde bulunduran döviz kuru kanalının Türkiye ekonomisinde etkin olduğu bulunmuştur.

\subsection{Teorik Literatür}

Bir ülkenin dış ticaretine etki eden birçok faktör vardır. Kur, ihracat ve ithalatı etkileyen faktörlerden biri ve belki de en önemlisidir. Kurda meydana gelen aşağı ve yukarı yönlü dalgalanmalar yapılan ihracat ve ithalat miktarının değişmesine sebep olmakta ve böylece dış ticaret açığı/fazlası oluşmaktadır.

Döviz kurundaki bir sapma, ister ham isterse anında veya nihai ürün olsun, malların ithalat ve ihracat fiyatlarını önemli ölçüde etkilemektedir (Ahmed vd., 2018: 62). Bir ülkenin para biriminin değer kazanması, ihracatın nispi fiyatını yükseltmekte ve ithalatının nispi fiyatını düşürmektedir. Buna karşılık ulusal parada oluşan bir değer düşüklüğü ise bir ülkenin ihracatının nispi fiyatını düşürmekte ve ithalatının nispi fiyatını yükseltmektedir (Krugman vd., 2012: 324). Ekonomik teoriye göre, politika yönergeleri genel olarak döviz amortismanının ( değerinin düşmesi) ihracatı teşvik ettiği ve ithalatı azalttığı varsayımı altında hareket ederken, dövizin değer kazanması ise ihracata zarar verir ve ithalatı teşvik etmektedir. Yurt içi döviz amortismanı (sabit döviz rejimlerindeki devalüasyon), yurt içi döviz cinsinden ithalatın fiyatını arttırır, bu da ithalatın daha pahalı olacağı anlamına gelir. Aynı zamanda, döviz (yabancı para) cinsinden ihracatın fiyatını düşürür; başka bir deyişle, ihracat daha ucuz hale gelir. Yukarıda verilenler göz önüne alındığında döviz amortismanının fiyat etkisi, ihracat hacmini artırabilir ve ithalat hacmini azaltabilir. Döviz kurları ters yönde çalışır; ancak, etkinin yoğunluğu, amortisman etkisinin altında olduğu durumla aynı olmayabilir (Šimáková, 2018: 422).

Yani ülke parası yabancı paralar karşısında değer kaybettiğinde ithal malların fiyatları artar ve bu durumda ithal mallar yurt içindeki tüketiciler açısından daha pahalı hale gelir. Yabancı ülkeler açısından ise ihraç malların fiyatları ucuzlar. Böylece ithal mallara olan yurt içi talep azalır ve ithalat düşer, ihraç mallara olan yurt dışı talep arttığı için ise ihracat artar ve bu durum sonucunda 
dış ticaret fazlası oluşur. Ülke parası yabancı paralar karşısında değer kazandığında ise ithal malların fiyatları ucuzlar, ithal mallara olan artan yurt içi talep ithalatı arttııır. Yabancılar açısından ise ihraç malları daha pahalı hale geldiği için azalan talep ihracatı azaltır ve dış ticaret açığı oluşur.

Nominal kurdaki değişmelerin ithalat fiyatlarında meydana getirdiği değişme etkisi "döviz kurunun geçiş etkisi" olarak ifade edilmektedir (Hooper ve Mann, 1989: 299). Döviz kurunda meydana gelen dalgalanmaların enflasyon üzerinde oluşturduğu etki, kurun fiyatlar üzerindeki geçiş etkisi yoluyla tanımlanmaktadır. Döviz kurunun ekonomik büyüme üzerindeki etkisi ise, serbest kur sisteminde döviz talebinde oluşan artış ile birlikte ulusal paranın değer kaybetmesi, ihracatta artış sağlarken ithalatı azaltacak ve dolayısıyla ekonomik büyüme olumlu etkilenecektir. Ülkedeki enflasyonu düşürmek amacıyla hükümetin sabit kur rejimini uygulaması sonucunda enflasyonun düşürülememesi, ulusal para biriminin değer kazanmasına neden olacak ve böylece ithalat artarken ihracat azalacak, ekonomik büyüme bu durumdan olumsuz etkilenecektir. Türkiye üzerine yapılan analizlerin çoğunda döviz kurunda oluşan değişmelerin TÜFE'den ziyade ÜFE üzerinde etkisi görülmüştür (Duman\&Sağdıç, 2019: 2-4).

Kurlardaki değişmelerin yurt içi fiyatları etkilediği döviz kuru geçiş etkisinin derecesi birçok faktöre bağlı olmakta ve bunlara göre değişebilmektedir. İthal edilen malların ÜFE ve TÜFE sepetleri içindeki payının artması, ürün farklılaştırmasının yapılabilmesi ve yurtdışı fiyatlarla fiyatlamanın gerçekleştirilmesi döviz kuru geçiş etkisini arttırmaktadır (Arı, 2010: 2840). Döviz kuru ile ithalat malları arasındaki etkileşimin göstergesi olan döviz kuru geçiş etkisinin düşük olması, kurun yurt içi fiyatlar üzerinde her zaman düşük etki oluşturacağı anlamına gelmez. Kur ile ithalat fiyatları arasında oluşan etkileşimi gösteren geçiş etkisi düzeyi, reel döviz kurunu ve nispi fiyatları, buna bağlı olarak satın alma gücünde oluşan nispi değişimleri göz ardı etmektedir. (Edwards, 2006: 4).

Bir parasal aktarım mekanizması kanalı olan döviz kuru kanalı, ekonomik göstergeler üzerinde etkiler yaratan önemli değişkenlerden biridir. Döviz kuru kanalı, faiz oranı kanalı üzerinden parasal aktarım mekanizmasını açıklamakta olup, para politikasının kurları etkilemesi ile bu etkinin net ihracata yansıması sonucunda hasıla düzeyinde oluşan değişimi ifade etmektedir. Dolayısıyla döviz kurlarının, net ihracat ve aynı zamanda faiz oranına da etkisi bulunmaktadır. Para otoritesinin ekonomide oluşan para arzını daraltması $(\mathrm{M} \downarrow)$, yurt içi reel faiz oranlarını arttırır (i个) ve sonuç olarak ulusal para birimi türünden varlıkların getirisi olumlu olarak etkilendiğinden, 
sermaye girişine yönelik teşvik olur ve ulusal para değerlenir. Ulusal paranın değerlenmesi ( $\mathrm{E} \uparrow$ ) ile yerli mallar dış mallar karşısında pahalı duruma gelir. Bunun sonucunda toplam üretim $(\mathrm{Y} \downarrow)$ ve net ihracat (NX $\downarrow$ ) azalır. Yurt içi reel faiz oranları düştüğünde ise tersi durumlar gerçekleşir: ulusal para değer kaybeder, yerli mallar yabancı mallara göre ucuzlar, toplam üretim ve net ihracat artar (Akbaş vd., 2013: 188; Uğur vd., 2016: 36-37).

Türkiye ekonomisi için döviz kurundaki değişmelerin ithalat ve ihracat üzerinden sanayi üretimim üzerinde yaratacağ etki ithalata bağımlı bir üretim yapısına sahip olunduğundan dolayı ters yönde etki etmektedir. Grafik 1'de 2001 yılının ikinci yarısıyla birlikte MB müdahaleleriyle sinırlandırılan serbest döviz kuru sisteminin ve ihracata dayalı büyüme modelinin tam anlamıyla uygulanması sonucunda, döviz kuru ve sanayi üretiminin analizimizde de kullandığımız 2005-2019 yılları arasındaki zaman itibariyle oluşan değişimine birlikte bakılmıştır. Grafik incelendiğinde, 2005 yılından 2006 yılına kadar döviz kuru ve sanayi üretiminin birlikte hareket ederek sürekli artış gösterdiği görülmektedir. 2006 yılının ilk çeyreğinde her iki değişkende ani bir düşüş yaşanmakta ve ikinci çeyrekle birlikte ikisinde de artış yaşanarak, 2009 yılına kadar iki değişken de dalgalı ve paralel bir seyir izlemektedir. 2009 yılında iki değişkende de ani bir düşüş görülmekte ve bu düşüşün 2008 krizinin etkisiyle meydana geldiği düşünülmektedir. 2009 y1lının ikinci çeyreği ile birlikte artış gösteren değişkenler, 2010 yılı ikinci çeyreğine kadar paralel olarak artış göstermiştir. 2010 yılı son çeyreğiyle birlikte düşmeye başlayan döviz kurları karşısında sanayi üretimi dalgalı artan bir seyir izlemiştir. 2011 yılından 2013 yılına kadar sürekli artan döviz kuru karşısında sanayi üretimi dalgalı ve genel olarak artan bir seyir izlemiştir. 2013 yılı son çeyreğinden 2017 yılı son çeyreğine kadar döviz kuru ve sanayi üretiminin dalgalı ve paralel bir seyir izlediği görülmektedir. 2017 yılından sonra iki değişken zıt bir şekilde ilerlemiş; döviz kurunun sürekli düştüğü görülürken sanayi üretiminin dalgalı ve artan bir seyir izlediği görülmektedir. Grafik genel olarak incelendiğinde, iki değişkenin 2014 y1lına kadar paralel olarak hareket ettiği görülürken, 2014 yılından sonra değişkenlerin zıt olarak hareket ettiği görülmektedir. Bu durum döviz kuru ile sanayi üretimi arasında uzun dönemli bir ilişkinin olabileceği konusunda bir şüphe doğurmaktadır. 


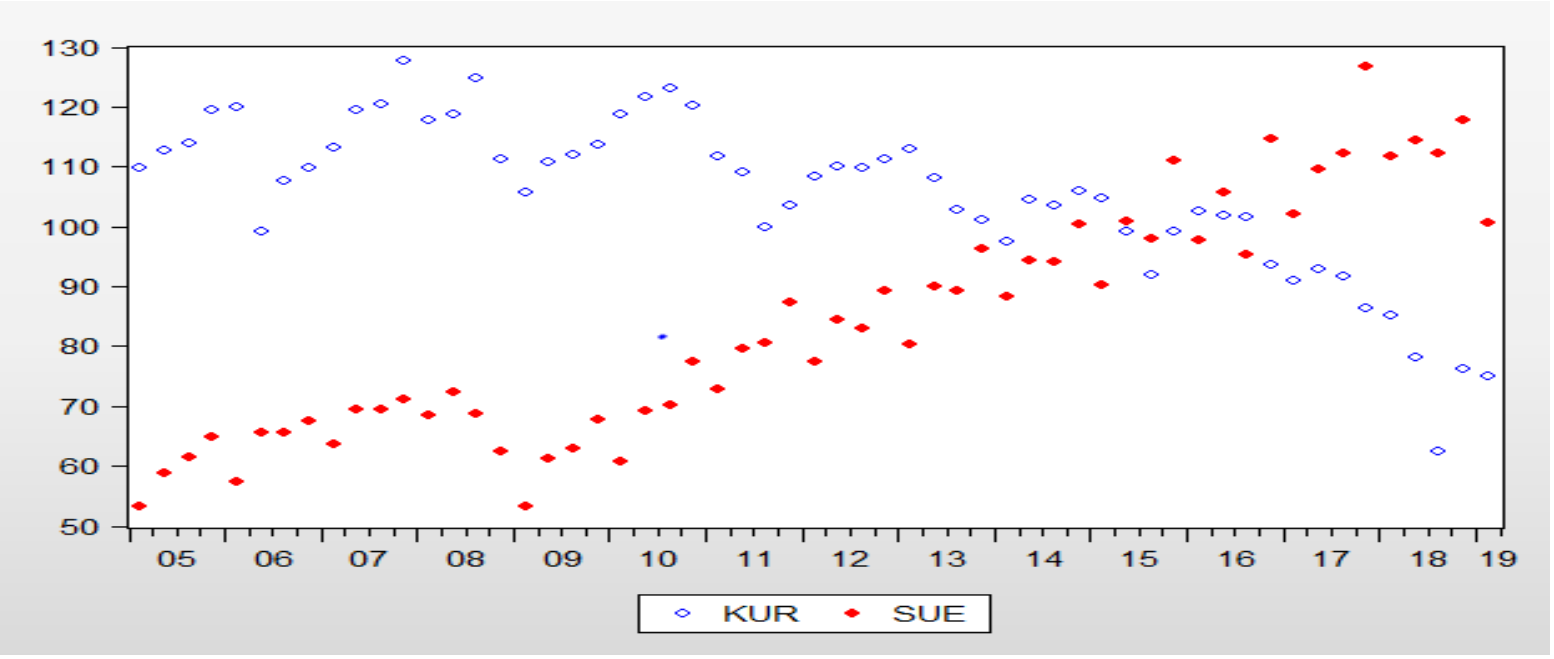

Grafik 1. Döviz Kuru ve Sanayi Üretim Endeksinin Zaman İtibariyle Değişiminin Birlikte Gösterimi (TCMB, EVDS)

\subsection{Ampirik Metodoloji}

Bu çalışmada, Türkiye'de döviz kuru ile sanayi üretimi arasındaki ilişki 2005:Q1-2019:Q1 dönemini kapsayan üçer aylık orjinal zaman serileri kullanılarak incelenmiştir. Çalışmada kullanılan makroekonomik değişkenler TÜFE Bazlı Reel Efektif Döviz Kuru ve Sanayi Üretim Endeksi, Toplam Sanayi verileridir. Bu veriler Türkiye Cumhuriyeti Merkez Bankası (TCMB) Elektronik Veri Dağıtım Sistemi (EVDS)'nden alınmıştır. Seriler arasındaki nedensellik ilişkisi zaman serileri analizleri yardımıyla analiz edilmiştir. $\mathrm{Bu}$ doğrultuda, Eviews 9 programı kullanılarak, hesaplamalar yapılmıştır.

\subsubsection{Zaman Serileri Analizi}

Zaman serisi yöntemi, değişkenlerin bir dönemden bir diğer döneme ardışık biçimde gözlendiği sayısal değerler ile ilgili bilgiler verir. İzlenen verilerin zaman içinde ardışık olması gerekli bir şart değildir ancak, düzenli zaman aralıklarında dizinin gelişiminin izlemesi doğru analiz açısından önemlidir. Bir zaman serisi günlük, haftalık, aylık, üç aylık, yıllık ya da daha uzun dönemli olan aralıklarla derlenip, toplanır. Sanayi Üretim Endeksi aylık, üç aylık ve yıllık olarak hesaplanmaktadır. Bu çalışmada üç aylık veriler kullanılmıştır. Aynı zamanda döviz kuru değişkeni de üç aylık olarak analizde kullanılmıştır.

$\mathrm{Bu}$ çalışmada değişkenler arasındaki nedensellik ilişkisinin tespit edilebilmesi için ilk aşamada söz konusu değişkenlere ait serilerin durağanlığı; Genişletilmiş Dickey-Fuller (ADF) 
birim kök testi ile analiz edilmiştir. $\mathrm{Bu}$ analizin sonucuna bağlı olarak seriler arasındaki uzun dönem ilişkisi Engle-Granger ve Phillips-Ouliaris Eş-Bütünleşme (Koentegrasyon) testleri ve hata düzeltme modeli Dinamik En Küçük Kareler (DEKK) yöntemi ile analiz edilmiştir. Nedensellik ilişkileri ise Toda-Yomamoto (1995) nedensellik testi yöntemiyle tahmin edilmiştir. Buraya kadar yapılan testler Eviews 9 programı kullanılarak analiz edilmiştir. Nedensellik testi uygulanması sonucu elde edilen değerler, iktisadi açıdan yorumlanmakta ve sonuç olarak, Türkiye’de döviz kuru ile sanayi üretimi arasındaki ilişki ekonometrik analiz ile belirlenmektedir.

\subsubsection{Birim kök testi (Dură̆anlık Analizi)}

Ekonometrik modeller, iktisat teorisi tarafından ortaya konulan denge ilişkileri üzerine kurulmaktadır. Durağan olmayan değişkenlerle yapılan ekonometrik analiz sonuçları sahte regresyona ve yanıltıcı sonuçlara sebep olmaktadır. Bu nedenle, değişkenler arasında ekonometrik olarak güvenilir sonuçlar ve anlamlı ilişkiler elde edilebilmesi için serilerinin durağan olması yani, birim kök taşımaması gerekmektedir. Bu amaçla analizde, öncelikle kullanılacak zaman serilerinin durağan olup olmadıklarının incelenmesi (birim kök sınamalarına gidilmesi), yanlış sonuçlara neden olmayacak en uygun olan ekonometrik tekniğin belirlenmesi için gereklidir. Dolayısıyla serilerin durağanlığı oldukça önemli olduğu için, birim kök testleri yapılarak değişkenlerin bütünleşme dereceleri tespit edilmektedir. Bu çalışmada, serilerin durağanlaştırılması için Dickey ve Fuller (1981) tarafından geliştirilen, doğrusal birim kök testi olan ve yapısal kırılmaları dikkate almayan ADF (Augmented Dickey-Fuller) Testi uygulanmıştır.

Genişletilmiş Dickey Fuller (ADF) (1979; 1981), serinin durağan yapısını kontrol etmek için gerçekleştirilir (Singh, 2016: 82). Verilerin zaman serisi olduğunu göz önünde bulundurarak, her parametrede Genişletilmiş Dickey-Fuller testi uygulanarak verilerin durağan olup olmadığının tespit edilmesi için Unit Root / testinin yapılması önemlidir (Misra, 2018: 76). Söz konusu test, bir zaman serisi uygulamasında kullanılacak değişkenlerin birim kök içerip içermediğinin yani, durağan olup olmadığının analizi için kullanılmakta olup, çok standart, çok kullanılan bir testtir. Serilerin birim köklü bulunması durumu, durağan olmadığı anlamına gelmektedir ve daha sonra kullanılan serilerin kaçıncı dereceden farkının alınması halinde durağan hale getirilebileceği bilgisine ulaşılmaktadır. ADF testinde, durağanlığı tespit etmek amacıyla sabitli, sabitsiz ve trendli bir sıralama izlenir. Eğer, seri trendli bir süreçte durağanlaşmışsa I(0), diğer süreçler izlenmeden kullanılan serinin ilk değerleri temel alınır. Seri durağanlaşmamışsa önce sabitli, bu süreçte de 
istenilen sonuç elde edilmemişse sabitsiz denemeler uygulanarak seri durağanlaştırılır (Cihangir ve Kandemir, 2010: 275).

Durağan olmayan zaman serilerini durağan hale getirebilmek amaciyla genel olarak serilerin birinci dereceden farkları alınır. Farkı alındığında zaman serisi durağanlaşıyorsa bu serinin birinci dereceden durağanlaştığı söylenir ve seri "I(1)" olarak gösterilir. Başka bir deyişle, zaman serisi n defa farkı alındığı zaman durağan oluyorsa, zaman serisinin n.dereceden durağan olduğu anlamına gelen "I(n)" biçiminde gösterilmektedir. Hesaplanan test istatistiğinin değeri çeşitli anlamlılık düzeylerine göre elde edilen MacKinnon kritik değerlerinden büyükse serinin birim köklü olduğu temel hipotezin kabul edildiği, küçükse serinin durağan olduğu alternatif hipotezin kabul edildiği sonucuna varılır.

$\mathrm{H}_{0}$ : Seri durağan değildir (Seri birim köke sahiptir).

$\mathrm{H}_{1}$ : Seri durağandır (Seri birim köke sahip değildir).

Eğer hesaplanan test istatistiği pozitifse direkt olarak birim kök temel hipotezinin reddedilemeyeceği sonucuna varılabilir.

\subsubsection{Eş-bütünleşme (Koentegrasyon) analizi}

Bir dizi zaman serisi değişkeni arasındaki ilişkiyi modellerken, verinin durağanlığını dikkate almak önemlidir. Birim kök içeren seriler arasında sahte bir regresyon problemi tespit ederken, bu problemi çözmek için bazı yöntemler önerilmektedir. En basit yollardan biri, serinin farklarını alıp standart bir regresyon modeli tahmin etmektir. Ancak, bu yöntem seviye ilişkileri için anlamlı olan bilgilerin kaybına neden olur. Değişkenlerin ilk farklarının kullanılması kaydıyla, seviyelerde potansiyel bir uzun vadeli ilişki belirlemek mümkün değildir. Bu noktadan hareketle, 1980'lerin sonlarında hata düzeltme modellemesi ile ilişkili ortak bütünleşme yaklaşımı geliştirilmiştir. Bu sayede hem kısa hem de uzun vadeli ilişki analiz edilebilir (Ghorbani and Motallebi, 2009).

Bir serinin entegrasyon derecesi bilindikten sonra, farklı entegrasyon serileri arasında bir ilişki kurmak ve değişkenlerden standart çıkarım yapmak mümkündür. Dură̆an olmayan değişkenler arasında durağanlık yaratma sürecine "eş-bütünleşme" denir. Eş-bütünleşme testi, bir modele ilave edilen seriler arasında sabit uzun dönemli bir ilişki olup olmadığını belirlemek 
amacıyla gerekli bir işlemdir. Seriler arasında eş-bütünleşme ilişkisi varsa, o sorunun üstesinden gelmek gereklidir (Adejumo ve Ikhide, 2019: 9).

Seriler arasında olabilecek eş-bütünleşme ilişkisi, serilerin uzun dönemde birlikte hareket ettiğinin bir göstergesidir. Eş-bütünleşme testi, iktisadi değişkenlere ait serilerin düzey değerde durağan olmasalar bile, durağan olan bir doğrusal kombinasyonunun bulunabileceği ve eğer varsa, bu kombinasyonun ekonometrik olarak belirlenebileceğini ileri sürmektedir. Birim kök içeren iki zaman serisi aynı dereceden entegre iseler, bu durumda iki seri arasında bir eş-bütünleşme olabilir ve aralarındaki regresyon yanıltıcı olmaz. Eş-bütünleşme analizi uzun dönem serilerinde fark almaktan dolayı oluşan çözümsüzlüğü ve bilgi kaybını önleyen bir yaklaşımdır. Eş-bütünleşme iki seri arasında nedenselliği gerektirir, fakat nedenselliğin yönünü göstermez. Eş-bütünleşme testleri arasında Phillips-Ouliaris (1988) kalıntı odaklı, Johansen (1990) çok değişkenli ve Engle-Granger (1987) iki aşamalı tahmin metodu testleri sayılabilir.

En önde gelen eş-bütünleşme testlerinden biri olan ve kalıntılara dayanan Engle-Granger testinin avantajları, sezgisel ve gerçekleştirmesi kolay olmasıdır. Test iki aşamada ilerler; ilk önce tüm değişkenlerin aynı entegrasyon düzeyinde olması gereken eş-bütünleşme regresyonunu tahmin ederek başlar. Bu denklem değişkenler arasında ekonomik olarak anlamlı bir denge ilişkisini temsil eder. Değişkenler arasında eş-bütünleşme varsa, ortak bir eğilimi paylaşacaklar ve değişkenler arasında uzun süreli bir ilişki olduğunu göstereceklerdir. İkinci adımda, ortaya çıkan kalıntı üzerinde bir birim kök testi gerçekleştirilir. ADF gerçekleştirilebilir ve daha sonra gecikme uzunluğunun belirlenmesi, böylece hataların beyaz gürültü haline gelmesi çok önemlidir (Adejumo ve Ikhide, 2019: 9-10).

Durağan olmayan serilerle, uzun süreli bir ilişkinin olup olmadığını incelemek için eşbütünleşme analizi kullanılmaktadır. Buna göre, kısa dönemde farklı hareket edebilen seriler, uzun dönemde ise denge ilişkisine yakınsamaktadırlar. Bununla birlikte, eş-bütünleşme tekniğinin kullanımı için gerekli bir koşul, söz konusu değişkenin aynı sırada entegre edilmesi gerektiği ve bütünleşik değişkenlerin doğrusal kombinasyonlarının birim kökünden arındırılmış olmasıdır. Bunun için Engle ve Granger (1987) kullanılan değişkenlerin bütünleşme derecelerinin belirlenmesi gerekliliği üzerinde durur. Birim köke sahip olan bir seri birinci farkı alındığı takdirde durağanlaşıyorsa birinci dereceden bütünleşik “I(1)” olmaktadır. Engle ve Granger (1987)'e göre, değişkenlerin eş-bütünleşik olduğu tespit edilirse, zaman içinde ayrılmazlar ve durağan olmayan 
değişkenler arasında uzun dönem kombinasyonu kurulabilir (Bilgin \& Şahbaz, 2009: 184; Singh, 2016: 83).

Phillips-Ouliaris (1988) ise "z-testi” ve "tau testi” şeklinde kalıntılar üzerine iki test geliştirmiştir. İkisi de birim kök testleri olarak kullanılır, ancak veriler eş-bütünleşme regresyonlarından bulunan kalıntılardır. Her iki test de çoklu seriler ya da matrisler üzerine uyarlanmakta ve birinci fark otoregresyon denkleminin (AR1) kalıntılarına dayanmaktadır. İlave olarak bu testlerde eş-bütünleşmenin olmadığını ifade eden sıfır hipotezi, eş-bütünleşmenin olduğu anlamına gelen alternatif hipoteze karşı test edilmektedir (Ecevit\& Çetin, 2016: 89).

Ayrıca serileri yapısal olarak kalıcı bir şekilde etkileyen kırılma tarihleri de eş-bütünleşme analizine dâhil edilmiştir. $\mathrm{Bu}$ şekilde, modeli etkileyebilecek yapısal kırılmalar düzeltilmiştir. Değişkenlerin arasında eş-bütünleşme ilişkisi olduğu durumunda, bir Vektör Hatası Düzeltme modeli çalıştırılması önerilir. Bununla birlikte, eğer eş-bütünleşme ilişkisi yoksa, VAR modeli çalıştırılmalıdır. Böylece, bu çalışmada kullanılan seriler için eş-bütünleşme ilişkisi bulunduğundan dolayı, Vektör Hata Düzeltme modeli ile çalıştırıldı. Analiz için Dinamik En Küçük Kareler (DEKK) yöntemi kullanılmıştır.

\subsubsection{Toda-Yomamoto Nedensellik Testi}

Toda ve Yomamoto (1995) tarafından önerilmiş olan dönüştürülmüş Wald testi (MWALD), Granger nedenselliği ile ilgili olan bir yöntemdir (Bilgin ve Şahbaz, 2009: 187). Granger nedensellik testinde kullanılan serilerin durağan olmaması halinde öncelikle değişkenler arasındaki eş-bütünleşme ilişkisine bakılır ve aralarında uzun dönemli bir ilişki bulunması durumunda hata düzeltme modeline dayalı olan nedensellik analizi uygulanır. Uzun dönemli bir ilişkinin bulunmaması durumunda ise serilerin bütünleşme derecesi kadar farkı alınarak eklendiği VAR modele dayalı olan nedensellik analizi yapılır. Söz konusu serilerin farkının alınması, yani granger nedensellik analizinin durağan seriler ile yapılması, birinci dereceden durağan olan seriler ile yapılacak analizlerde bilgi kaybına sebep olacaktır. Eş-bütünleşme ilişkisinin var olup olmadığına bakılması ise ön test eğimlerine yol açabilir. Toda ve Yomamoto (1995) bu sorunların üstesinden gelebilmek amaciyla VAR modele, söz konusu serilerin maksimum bütünleşme seviyesi kadar ilave gecikme eklenmesini önermiştir (Bozoklu\&Yılancı, 2014: 215).

Toda-Yomamoto nedensellik testi, bütünleşik ve eş-bütünleşme süreçleri ile genişletilmiş olan VAR modeli üzerinden nedensellik analizine imkan verir ve ayrıca potansiyel biçimde yanlı 
olma özelliğine sahip olan birim kök ve eş-bütünleşme ön testlerine gerek duymadığından dolayı daha uygun olan bir yöntemdir. Toda ve Yomamoto (1995) yöntemi, VAR (k) modelinin parametreleri üzerinde sınırlamaları test etmek için değiştirilmiş bir Wald (MWALD) testini kullanır. Bu yöntemin uygulanmasında iki adım vardır. İlk adım, gecikme uzunluğunun (k) ve sistemdeki değişkenlerin maksimum entegrasyon sırasının (d) belirlenmesini içerir. VAR'ın uygun gecikme yapısını belirlemek için Akaike Bilgi Kriteri (AIC) ve Hannan-Quinn (HQ) Bilgi Kriteri gibi ölçütler kullanılabilir. İkinci adım, Granger nedensellik üzerine çıkarım yapmak için birinci k VAR katsayısı matrisine (ancak tüm gecikmeli katsayılar değil) standart Wald testleri uygulamaktır (O.Awokuse, 2002: 7-8). Toda-Yomamoto (1995) nedensellik testi uygulanan her serinin seviyesinde durağanlaştığı durumda, VAR modele ilave gecikme eklenmemektedir. Bu durumda Toda-Yomamoto (1995) testi ile Granger nedensellik analizi birbirine benzer sonuçlar göstermektedir (Şentürk \& Akbaş, 2014: 5825-5826).

Bundan dolayı bu çalışmada, döviz kuru ve sanayi üretim endeksi değişkenleri arasındaki nedensellik ilişkisinin araştırılmasında ve değişkenler arasındaki ilişkinin yönünün belirlenmesinde bir "Granger Nedensellik Analizi”" olan ve analiz edilen dönem dikkate alınarak serilerin düzey değerleri ile çalışmanın mümkün olduğu Toda-Yomamoto (TY) nedensellik analizi kullanılmıştır. $\mathrm{Bu}$ analize göre, Granger Nedensellik Testi'nde ulaşılan olasılık değerleri 0,05 anlamlılık düzeyinden büyükse; $\mathrm{H}_{0}$ hipotezleri kabul edilmekte, küçükse oluşturulan sıfır hipotezleri reddedilmekte, $\mathrm{H}_{1}$ alternatif hipotezleri kabul edilmektedir.

$\mathrm{H}_{0}$ : Nedensellik yok.KUR, SUE'nin granger anlamda nedeni değildir.

$\mathrm{H}_{1}$ : Nedensellik var. KUR, SUE'nin granger anlamda nedenidir.

$\mathrm{H}_{0}$ : Nedensellik yok SUE, KUR'un granger anlamda nedeni değildir.

$\mathrm{H}_{1}$ : Nedensellik var. SUE, KUR'un granger anlamda nedenidir.

\section{Bulgular}

\subsection{Birim Kök Testi Sonuçları}

Nedensellik analizinin uygulanabilmesi için, öncelikle zaman serilerinin durağan olması gerekmektedir. Durağanlık analizini kolaylaştırabilmek amacıyla, birim kök testi yapılmadan önce KUR ve SUE olarak isimlendirilen değişkenlerimizin otokorelasyon sorunundan ve mevsimsellikten arındırılabilmesi için logaritmaları alınmıştır. Daha sonra KUR ve SUE zaman 
serileri öncelikle Augmented Dickey Fuller (ADF) birim kök analizi yapılarak durağan hale getirilmiştir. Yapılan analiz sonucunda, serilerin düzey değerlerinin durağan olmadığı tespit edildikten sonra farkları alınmış olan değerlerine tekrar birim kök testi uygulanmıştır. Söz konusu verilerin ADF birim kök testi uygulandıktan sonra hem düzey değerlerindeki tespit edilen durağan olmayan hem de birinci farkları alındıktan sonra durağan hale gelen sonuçları Tablo 1'de sunulmuştur.

Tablo 1

Birim Kök Testi Sonuçları

\begin{tabular}{|c|c|c|c|c|c|c|}
\hline \multicolumn{7}{|c|}{ ADF Birim Kök Testi (Sabitli) } \\
\hline \multicolumn{7}{|c|}{ Düzey I(0) } \\
\hline \multirow[t]{2}{*}{ Değişkenler } & \multirow{2}{*}{$\begin{array}{l}\text { ADF-Test } \\
\text { İstatistiği }\end{array}$} & \multicolumn{3}{|c|}{ Kritik Değer } & \multirow{2}{*}{$\begin{array}{l}\text { Gecikme } \\
\text { Uzunluğu }\end{array}$} & \multirow{2}{*}{$\begin{array}{l}\text { Olasilık } \\
\text { Değeri }\end{array}$} \\
\hline & & $\% 1$ & $\% 5$ & $\% 10$ & & \\
\hline KUR & 0.770513 & -3.562669 & -2.918778 & -2.597285 & 4 & 0.9926 \\
\hline SUE & -0.779240 & -3.565430 & -2.919952 & -2.597905 & 5 & 0.8164 \\
\hline \multicolumn{7}{|c|}{ Birinci Fark I(1) } \\
\hline \multirow[t]{2}{*}{ Değişkenler } & ADF-Test & \multicolumn{3}{|c|}{ Kritik Değer } & Gecikme & Olasilık \\
\hline & İstatistiği & $\% 1$ & $\% 5$ & $\% 10$ & Uzunluğu & Değeri \\
\hline KUR & -4.988413 & $-3.562669^{*}$ & $-2.918778^{* *}$ & $-2.597285 * * *$ & 3 & 0.0001 \\
\hline SUE & -2.983451 & -3.565430 & $-2.919952 * *$ & $-2.597905 * * *$ & 4 & 0.0432 \\
\hline
\end{tabular}

Not. Model spesifikasyonu otonom parametrenin olduğu sabitli model seçilmiştir. Analizde t-istatistik kriterine dayanarak, maksimum 10 gecikme uzunluğu arasından en fazla 5 gecikmeli model uygun olarak seçilmiştir. *** ve ***; surasıyla $\% 1, \% 5, \% 10$ düzeyinde istatistiksel olarak anlamlllı̆̆ göstermektedir. KUR ve SUE değişkenlerinin $\mathrm{ADF}$ test istatistik değerleri, McKinnon (1996) tarafindan geliştirilen \%1, \%5, ve \%10 güven aralığındaki kritik değerlerle karşılaştırılarak birim kökün varlığı analiz edilmiştir. $\mathrm{H}_{0}$ : temel hipotezi serinin birim kök içerdiğini, $\mathrm{H}_{1}$ : alternatif hipotezi ise serinin durağan olduğunu ifade etmektedir.

ADF birim kök testi sonuçları yorumlanırken değişkenlerin durağan olup olmadığını anlamak için iki değer bulunmaktadır. Birincisi olasılık değeri, ikincisi t-istatistik değeridir. Olasılık değeri yorumlanırken 0.05 anlamlılık düzeyi temel alınır. Yani değişkenlerin olasılık değerleri 0.05 'ten büyük ise seri birim kök içermekte, küçük ise seri durağan olmaktadır. Tistatistik değerleri yorumlanırken ise, $\% 1, \% 5$ ve $\% 10$ kritik değerleri ile karşılaştırılır. T-istatistik değeri kritik değerlerden büyük ise seri birim köklü, küçük ise seri durağan olmaktadır.

Tablo 1'de sabitli sürece göre düzey farklarında $I(0)$ olasılık değerleri 0,05 'ten büyük olduğundan ve t-Statistik değerleri $\% 1, \% 5$ ve $\% 10$ kritik değerlerinden daha yüksek bulunduğundan KUR ve SUE serileri birim kök içermektedir, yani söz konusu seriler durağan 
değildir. Bu durumda temel hipotez kabul edilir, alternatif hipotez reddedilir. Düzeyde durağan değilse KUR ve SUE serilerine gelen şoklar kalıcı bir etkiye sahiptir. Dolayısıyla KUR ve SUE serilerinin ekonometrik çalışmada kullanılabilir duruma gelebilmesi için serilere 1.mertebeden fark alma işlemi uygulanmıştır. Seriler D(LKUR) ve D(LSUE) olarak isimlendirilmiştir ve durağanlık analizi yapılmıştır.

Tablo 1'de sabitli sürece göre KUR ve SUE serilerinin birinci farkı I(1) alındığında, olasılık değerleri 0,05'ten küçük olduğundan ve t-istatistik değeri KUR değişkeninde \%1, \%5, \%10 kritik değerlerinden, SUE değişkeninde ise \%5 ve \%10 kritik değerlerinden daha küçük çıktığından KUR ve SUE serileri durağandır, birim kök içermemektedir. Bu durumda temel hipotez reddedilir, alternatif hipotez kabul edilir. ADF test istatistiği kullanılarak durağanlığı test edilen serilerin durağan halleri I(1), ekonometrik olarak çalışmanın yorumlanması için anlamlı bulunmuştur. Eşbütünleşme analizinin uygulanabilmesi için değişkenlerin durağanlaşması gerekmektedir. $\mathrm{Bu}$ bağlamda, ADF birim kök analizi sonucunda KUR ve SUE serileri aynı mertebeden I(1) durağan (bütünleşik) bulundukları için, uzun dönemli denge ilişkisini ifade eden eş-bütünleşme (koentegrasyon) testinin uygulanabilme koşulu sağlanmıştır. Eş-bütünleşme ilişkisinin bulunması, değişkenler arasında uzun dönem içinde bir dengenin var olduğu anlamına gelecektir.

\subsection{Eş-Bütünleşme (Koentegrasyon) Analizi Sonuçları}

Serilerin birinci farkı alındığı takdirde durağan olma ön koşulunu sağlaması ve bütünleşik olması sebebiyle çalışmanın bu bölümünde serilerin birlikte hareket edip etmediğini analiz edebilmek amacıyla Engle-Granger ve Phillips-Ouliaris Eş-Bütünleşme (Koentegrasyon) testleri uygulanmıştır.

Model 1: $\mathrm{SUE}_{\mathrm{t}}=\beta_{0}+\mathrm{KUR}_{\mathrm{t}}+\mathrm{e}_{\mathrm{t}}$

Model 2: $\mathrm{KUR}_{\mathrm{t}}=\beta_{0}+\mathrm{SUE}_{\mathrm{t}}+\mathrm{e}_{\mathrm{t}}$

Model 1'de sanayi üretim endeksi bağımlı değişken olarak alınırken, döviz kuru bağımsız değişken olarak seçilmiştir. Model 2'de ise döviz kuru bağımlı değişken olarak alınırken, sanayi üretim endeksi ise bağımsız değişken seçilmiştir. Engle-Granger ve Phillips-Ouliaris EşBütünleşme (Koentegrasyon) testi sonuçları "Tablo 3"de gösterilmiştir. 
Tablo 2

Eş-Bütünleşme Analizi Sonuçları

\begin{tabular}{|c|c|c|c|c|}
\hline \multicolumn{5}{|c|}{ Engle- Granger (1997) Eş-Bütünleşme Testi } \\
\hline Dependent & tau-statistic & Prob. ${ }^{*}$ & Z-statistic & Prob. $^{*}$ \\
\hline LSUE & -1.274761 & 0.8390 & -4.406227 & 0.7701 \\
\hline LKUR & -2.775167 & 0.1901 & -32.51945 & $0.0009^{* *}$ \\
\hline \multicolumn{5}{|c|}{ Phillips-Ouliaris (1998) Eş-Bütünleşme Testi } \\
\hline Dependent & tau-statistic & Prob.* & z-statistic & Prob. $^{*}$ \\
\hline LSUE & -3.538476 & $0.0406^{* *}$ & -17.61075 & 0.0629 \\
\hline LKUR & -3.177850 & 0.0892 & -19.47410 & $0.0395^{* *}$ \\
\hline
\end{tabular}

Not. Engle-Granger ve Phillips-Ouliaris eş-bütünleşme (koentegrasyon) testinde, otonom (constant) parametre kullanılmıştır. Eş-bütünleşme testlerine dahil edilen gözlem sayıs1 57'dir. Gecikme uzunluğu Engle-Granger testinde t-istatistik kriterine $(\operatorname{maxlag}=10)$ göre belirlenmiştir. Phillips-Ouliaris testinde ise uzun dönem varyans tahmini (Bartlett çekirdeği, Newey-West sabit bant genişliği) yapılmıştır. "LSUE" SUE'nin bağımlı değişken olarak seçildiği "Model 1" için gerçekleştirilmiştir. "LKUR" KUR'un bağımlı değişken olarak seçildiği "Model 2" için gerçekleştirilmiştir. Sonuçlar yorumlanırken $\% 5$ (**) anlamlılık düzeyi temel alınmış ve t-istatistik ve z-istatistik olasılık değerleri (prob) \%5 anlamlılık düzeyi ile karşılaştırılmıştır. $\mathrm{H}_{0}$ : eş-bütünleşme ilişkisinin olmadığı anlamına gelen temel hipotezi ve $\mathrm{H}_{1}$ : eş-bütünleşme ilişkisinin olduğu anlamına gelen alternatif hipotezi ifade etmektedir.

Tablo 2'de Engle-Granger eş-bütünleşme (koentegrasyon) test sonucuna göre; SUE'nin bağımlı değişken olarak seçildiği kısımda t-istatistik ve z-istatistik olasılık değeri (prob) 0.05 'ten büyük olduğu için eş-bütünleşme yoktur. Temel hipotez kabul edilmekte, alternatif hipotez reddedilmektedir. Bu sonuç, "model 1"in Engle-Granger eş-bütünleşme testi için anlamlı olmadığını göstermektedir. KUR'un bağımlı değişken olarak seçildiği kısımda z-istatistik olasılık değeri (**) 0.05 'ten küçük olduğu için eş-bütünleşme ilişkisi vardır. Temel hipotez reddedilmekte, alternatif hipotez kabul edilmektedir. Yani "model 2" bu test için anlamlı bulunmuştur.

Tablo 2'de Phillips-Ouliaris eş-bütünleşme (koentegrasyon) test sonucuna göre; SUE'nin bağımlı değişken olarak seçildiği kısımda t-istatistik olasılık değeri (**) 0.05 'ten küçük olduğu için eşbütünleşme ilişkisi vardır. Temel hipotez reddedilmekte, alternatif hipotez kabul edilmektedir. Yani "model 1" bu test için anlamlı bulunmuştur. KUR'un bağımlı değişken olarak seçildiği kısımda z-istatistik olasılık değeri (**) 0.05'ten küçük olduğu için eş-bütünleşme ilişkisi vardır. Temel hipotez reddedilmekte, alternatif hipotez kabul edilmektedir. Yani "model 2" bu test için anlamlı bulunmuştur. 
Engle-Granger z-istatistik ve Phillips-Ouliaris t-istatistik ve z-istatistik sonuçları, döviz kuru ve sanayi üretim endeksi arasında uzun dönem denge ilişkisinin var olduğunu göstermektedir. Yapılan her iki eş-bütünleşme testi sonucunda KUR'un bağımlı değişken olarak alındığı Model 2'nin daha anlamlı olduğu görülmektedir.

DEKK (Dinamik En Küçük Kareler) eş-bütünleşme katsayıları, hata düzeltme testinin yapılabilmesi için gerekli bir ön testtir. DEKK testinde, ortalamanın (C) ve varyansın (LKUR, LSUE) olasılık değeri 0.05 ten küçükse parametre istatistiksel olarak anlamlıdır. Dolayısıyla bu çalışmada "Tablo 4"de görüldüğü üzere, hem SUE'nin bağımlı değişken olarak alındığı Model 1'in hem de KUR'un bağımlı değişken olarak alındığı Model 2'nin olasılık değerleri (**) 0.05'ten küçük olduğu için parametreler anlamlı görünmektedir. Ayrıca KUR ve SUE değişkenlerinin katsayılarının sırasıyla "-0.21" ve "-0.43" (*) olması, döviz kuru ile sanayi üretim endeksi arasında uzun dönemde anlamlı ve negatif bir ilişkinin olduğunu göstermektedir. Özellikle de KUR'un bağımlı değişken olarak alındığı "Model 2"de SUE değişkeninin katsayısına bakıldığında (-0.43), eş-bütünleşme testlerinin sonuçlarıyla tutarlı olarak katsayı tahmininde de bu modelin daha anlamlı olduğu görülmektedir.

Tablo 3

DEKK Eş-Bütünleşme Katsayıları

\begin{tabular}{|c|c|c|c|c|}
\hline \multicolumn{5}{|c|}{ Dependent Variable: LSUE } \\
\hline Variable & Coefficient & Std. Error & t-Statistic & Prob. \\
\hline LKUR & $-1.214065^{*}$ & 0.154516 & -7.857200 & $0.0000^{* *}$ \\
\hline C & 10.04506 & 0.718596 & 13.97873 & $0.0000^{* *}$ \\
\hline \multicolumn{5}{|c|}{ Dependent Variable: LKUR } \\
\hline Variable & Coefficient & Std. Error & t-Statistic & Prob. \\
\hline LSUE & $-0.435602^{*}$ & 0.055440 & -7.857200 & $0.0000^{* *}$ \\
\hline C & 6.565843 & 0.244338 & 26.87193 & $0.0000^{* *}$ \\
\hline
\end{tabular}

Not. SUE'nin ve KUR'un bağımlı değişken olduğu model için yapılan eş-bütünleşme testlerinin anlamlılığını sınamak için, her iki model için ayrı bir şekilde uzun dönem katsayıları Dinamik EKK (DOLS) kullanılarak tahmin edilmiş ve "Tablo 4"de birlikte gösterilmiştir. DEKK eş-bütünleşme katsayı tahminlerinde dahil edilen gözlem sayısı 57'dir. Sonuçlar yorumlanırken LKUR ve LSUE değişkenlerinin (variable) katsayısı (*) ile söz konusu değişkenlerin ve ortalamanın (C) olasılık değerleri (**) dikkate alınmıştır. Olasılık değerleri (**) için \%5 anlamlılık düzeyi temel alınmış ve değişkenlerin katsayısı "*" ile ifade edilmiştir.

Değişkenler arasında uzun dönemli olan bir eş-bütünleşme (koentegrasyon) ilişkisi varsa, değişkenlere hata düzeltme modelleri uygulanır. Hata düzeltme modelleri, uzun dönemli ilişkiden 
yani dengeden sapmayı gösterir. Seriler arasında eş-bütünleşme ilişkisine bakılabilmesi için serilerin durağan olması gerekir. Eğer seriler düzey değerde durağan değillerse, durağanlığın sağlanması amacıyla serilere fark işlemi uygulanır. Ancak bu fark işlemi uygulandığı zaman uzun dönem bilgisinde kayıplar meydana gelmektedir. Bu fark alma işlemi zaman serilerinin geçmişte etkilendiği geçici şokların oluşturduğu etkiyi ortadan kaldırdığı gibi, bu değişkenler arasında uzun dönemde olabilecek ilişkileri de yok etmektedir. Bundan dolayı oluşabilecek dengesizliklerin ortadan kaldırılması için serilere hata düzeltme modelleri uygulanır. Hata terimlerinin düzey değerde durağan bulunması gerekmektedir. Hata düzeltme modelleri uygulanırken durağan değişkenler ile kurulan modele, hata terimlerinin bir gecikmeli hali ilave edilir. Hata terimlerinin katsayısının "-1 ile 0" aralığında olması gerekmektedir. Eğer bu kısıt sağlanamazsa hata düzeltme modeli mekanizması çalışmıyor demektir.

Tablo 4

\section{DEKK Hata Düzeltme Modeli}

\begin{tabular}{|c|c|c|c|c|}
\hline \multicolumn{5}{|c|}{ Dependent Variable: D(LSUE) } \\
\hline Variable & Coefficient & Std. Error & t-Statistic & Prob. \\
\hline D(LKUR) & -0.070607 & 0.187017 & -0.377541 & $0.7073^{* *}$ \\
\hline ECT(-1) & $-0.186066^{*}$ & 0.078050 & -2.383942 & $0.0207^{* *}$ \\
\hline C & 0.011491 & 0.011583 & 0.992039 & 0.3257 \\
\hline \multicolumn{5}{|c|}{ Dependent Variable: D(LKUR) } \\
\hline Variable & Coefficient & Std. Error & t-Statistic & Prob. \\
\hline D(LSUE) & -0.009401 & 0.096998 & -0.096917 & $0.9232^{* *}$ \\
\hline ECT(-1) & $-0.250856^{*}$ & 0.096234 & -2.606717 & $0.0118^{* *}$ \\
\hline C & -0.005599 & 0.008499 & -0.658819 & 0.5129 \\
\hline
\end{tabular}

Not. SUE'nin ve KUR'un bağımlı değişken olduğu model için yapılan eş-bütünleşme testlerinin anlamlılığını sınamak için, her iki model için ayrı bir şekilde uzun ve kısa dönem vektör hata düzeltme modeli Dinamik EKK (DOLS) yöntemi kullanılarak tahmin edilmiş ve "Tablo 5 "de birlikte gösterilmiştir. Hata düzeltme modelleri uygulanırken durağan değişkenler ile kurulan modele, hata terimlerinin bir gecikmeli hali (ECT (-1)) ilave edildiğinden dolay1 (2005:Q2-2019:Q1), dahil edilen gözlem sayıs1 56'dir. Sonuçlar yorumlanırken Model 1 ve Model 2'nin hata terimi parametresi (ECT)'nin katsayı $(*)$ ve olasılık değerleri $(* *)$ ile $\mathrm{D}($ LKUR) ve $\mathrm{D}(\mathrm{LSUE})$ değişkenlerinin (variable) olasılık değerleri $(* *)$ dikkate alınmıştır. Olasılık değerleri $(* *)$ için $\% 5$ anlamlılık düzeyi temel alınmış ve değişkenlerin katsayısı "*" ile ifade edilmiştir.

Tablo 4'de sunulan DEKK hata düzeltme modeli sonuçlarına göre; hata düzeltme modeli (kısa dönem analizi) tahmini neticesinde, farkı alınmış olan KUR ve SUE değişkenlerinin olasılık değerleri (sırasılla $0.7073 * *$ ve $0.9232 * *$ ) \%5 anlamlılık düzeyinden büyük oldukları için 
değişkenler arasında kısa dönem ilişkisine rastlanmamıştır. Ancak, hata düzeltme testi sonucunda, modellere ilave edilen hata serisinin bir gecikmeli değeri için bulunan parametrelerin (ECT(-1)) katsayılarının sırasıyla "-0,18* ve $-0.25 *$ " şeklinde negatif değerler alması ve olasıllı değerlerinin de $(0.0207 * *$ ve $0.0118 * *) \% 5$ anlamlılık düzeyinden küçük olması, hata düzeltme modelinin istatistiki olarak anlamlı olduğunu göstermektedir.

Hata düzeltme terimi parametresi (ECT)'nin katsayısı, geçen yıl dengede meydana gelen bir bozulmanın, bu dönem içinde ne kadar düzeldiğini gösterir. ECT'nin katsayısının negatif ve istatistiki olarak anlamlı bulunması, kullanılan değişkenlerden herhangi birinde olabilecek bir şokun etkisinin uzun dönemde düzeleceği ve değişkenlerin tekrar birlikte hareket halinde olacağ 1 şeklinde yorumlanır.

Tablo 4'deki testin sonuçlarına göre, her iki model için gerçekleştirilen hata düzeltme parametreleri (ECT(-1))'nin katsayılarının sırasıyla "-0,18*" ve "-0.25*" olması, SUE'nin bağımlı değişken olduğu Model 1 için uzun dönemde meydana gelen bir şokun yaklaşık \%19'unun ve KUR'un bağımlı değişken olduğu Model 2 için yaklaşık \%25'inin sonraki dönem düzeleceğini ifade

etmektedir. Kısa dönemdeki dengesizlikler uzun dönemde bu şekilde kapanmaktadır. Bu testin sonucuna bakıldığında, uygulanan eş-bütünleşme testlerinin sonuçlarıyla tutarlı bir şekilde Model 2'nin daha anlamlı olduğu görülmektedir. Sonuç olarak bu çalışmada ulaşılan bulguların iyi durumda olduğu, yani hata düzeltme mekanizmasının çalıştığı, uygulanan eş-bütünleşme analizlerinin tutarlı olduğu ve uzun dönemde ilişkili olacağı sonucuna varılır.

\subsection{Nedensellik Analizi Sonuçları}

Bu çalışmada son olarak modellere eklenen KUR ve SUE değişkenleri arasındaki ilişkinin yönünü hesaplamak amacıyla Granger Nedensellik Analizi yapılmış ve Toda-Yomamoto yönteminden elde edilen sonuçlar Tablo 7'de gösterilmiştir. Öncelikle nedensellik analizi için belirlenen uygun gecikme uzunluğu Tablo 6 'da sunulmuştur.

Tablo 5'e göre KUR ve SUE değişkenleri arasında nedensellik analizi yapmak için VAR modele uygun gecikme uzunluğu LR, FPE AIC, SC, HQ kriterlerine göre "5" olarak belirlenmiştir. 
Tablo 5

VAR Modelinde Uygun Gecikme Uzunluğunun Belirlenmesi

\begin{tabular}{|c|c|c|c|c|c|c|}
\hline \multicolumn{7}{|c|}{ VAR Lag Order Selection Criteria } \\
\hline Lag & LogL & LR & FPE & AIC & SC & HQ \\
\hline 0 & 54.88000 & NA & 0.000449 & -2.033846 & -1.958798 & -2.005074 \\
\hline 1 & 124.9609 & 132.0756 & $3.53 \mathrm{e}-05$ & -4.575421 & -4.350277 & -4.489106 \\
\hline 2 & 137.3046 & 22.31355 & $2.57 \mathrm{e}-05$ & -4.896331 & -4.521092 & -4.752473 \\
\hline 3 & 140.9307 & 6.275982 & $2.61 \mathrm{e}-05$ & -4.881951 & -4.356616 & -4.680550 \\
\hline 4 & 150.1708 & 15.28158 & $2.14 \mathrm{e}-05$ & -5.083490 & -4.408060 & -4.824546 \\
\hline 5 & 163.6481 & $21.25279^{*}$ & $1.50 \mathrm{e}-05^{*}$ & $-5.448005^{*}$ & $-4.622479^{*}$ & $-5.131518^{*}$ \\
\hline
\end{tabular}

Not. Tablo 5'de KUR ve SUE değiş̧kenleri için VAR modele uygun gecikme uzunluğu kriteri belirlenmiştir. Model spesifikasyonu otonom parametrenin olduğu sabitli model dış değişken olarak seçilmiştir. Modele dahil edilen gözlem sayısı 52'dir."*" kriter tarafından seçilen gecikme uzunluğunu belirtir. LR: sıralı değiştirilmiş LR test istatistiği (her bir test $\% 5$ seviyesinde), FPE: Final prediction error (Son tahmin hatası), AIC: Akaike information criterion (Akaike bilgi kriteri), SC: Schwarz information criterion (Schwarz bilgi kriteri), HQ: Hannan-Quinn information criterion (Hannan-Quinn bilgi kriteri) şeklinde ifade edilmektedir.

Tablo 6

Doğrusal Toda-Yomamoto Nedensellik Analizi Sonuçları

\begin{tabular}{|c|c|c|c|}
\hline \multicolumn{4}{|c|}{ VAR Granger Causality/Block Exogeneity Wald Tests } \\
\hline \multicolumn{5}{|c|}{ Dependent variable: LSUE } & Prob. \\
\hline Excluded & Chi-sq & Df & $0.5641^{* *}$ \\
\hline LKUR & 3.898907 & 5 & 0.5641 \\
\hline All & 3.898907 & 5 & Prob. \\
\hline \multicolumn{4}{|c|}{ Dependent variable: LKUR } \\
\hline Excluded & Chi-sq & Df & $0.1226^{* *}$ \\
\hline LSUE & 8.678673 & 5 & 0.1226 \\
\hline All & 8.678673 & 5 & \\
\hline
\end{tabular}

Not. Tablo 6'da SUE'nin bağımlı değiş̧ken olarak alındığı "Model 1" ve KUR'un bağımlı değişken olarak alındığı "Model 2" için yapılan Garanger Nedensellik testinin sonuçları yer almaktadır. Gecikme uzunluğu "5" olarak belirlenmiş olup, modele dahil edilen gözlem sayısı 52'dir. "**" \%5 anlamlılık düzeyini ifade etmekte olup, olasıllk değerlerinin (prob) test edilmesinde $\% 5$ anlamlılık düzeyi temel alınmıştır. $\mathrm{H}_{0}$ : temel hipotezi nedenselliğin olmadığını, $\mathrm{H}_{1}$ : alternatif hipotezi ise nedenselliğin olduğunu göstermektedir.

Tablo 6'deki test sonucuna göre olasılık değerleri 0.05 ten büyük olduğu için aşağıda gösterilen temel hipotezler kabul edilirken alternatif hipotezler reddedilmiştir

$\mathrm{H}_{0}$ : Nedensellik yok. KUR, SUE'nin granger anlamda nedeni değildir. 
$\mathrm{H}_{1}$ : Nedensellik var. KUR, SUE'nin granger anlamda nedenidir.

$\mathrm{H}_{0}$ : Nedensellik yok. SUE, KUR'un granger anlamda nedeni değildir.

$\mathrm{H}_{1}$ : Nedensellik var. SUE, KUR'un granger anlamda nedenidir.

Toda-Yamamoto nedensellik testi sonucunda, \%5 anlamlılık seviyesinde KUR'dan SUE'ye ve SUE'den KUR'a herhangi bir nedensellik ilişkisi bulunamamıştır. Dolayısıyla döviz kuru ve sanayi üretim endeksi arasında uzun dönemli herhangi bir nedensellik ilişkisinin olmadığı tespit edilmiştir.

\section{Sonuç}

Çalışmadan elde edilen bulgulara göre sanayi üretimi ve döviz kuru arasındaki uzun dönemli ilişkinin varlı̆̆ını araştırmak üzere yapılan eş-bütünleşme analizleri sonucunda, döviz kuru ve sanayi üretim endeksi arasında uzun dönem ilişkisi bulunmuştur. Yapılan her iki eş-bütünleşme testi sonucunda KUR'un bağımlı değişken olarak alındığı Model 2'nin daha anlamlı olduğu görülmektedir.

Dinamik EKK (DOLS) testi kullanılarak tahmin edilen uzun dönem katsayıları sonucunda; ortalamanın (C) ve varyansın (LKUR, LSUE) olasılık değeri 0.05'ten küçük olduğu için Model 1 ve Model 2'de parametreler istatistiksel olarak anlamlı bulunmuştur. Ayrıca KUR ve SUE değişkenlerinin katsayıları döviz kuru ile sanayi üretim endeksi arasında uzun dönemde anlamlı ve negatif bir ilişkinin olduğunu göstermiştir.

DEKK hata düzeltme modeli sonuçlarına göre; hata düzeltme modeli (kısa dönem analizi) tahmini neticesinde, değişkenler arasında kısa dönem ilişsisine rastlanmamıştır. Ancak her iki değiş̧ken için hata düzeltme terimi parametrelerinin (ECT(-1)) katsayılarının negatif ve olasılık değerlerinin istatistiki olarak anlamlı bulunması; hata düzeltme mekanizmasının çalıştı̆̆ını, uygulanan eşbütünleşme analizinin tutarlı olduğunu, döviz kuru ile sanayi üretim endeksi değişkenlerinin herhangi birinde olabilecek bir şokun etkisinin uzun dönemde düzeleceğini ve değişkenlerin tekrar birlikte hareket edeceğini göstermiştir. Kısa dönemdeki dengesizlikler uzun dönemde bu şekilde kapanmaktadır. DEKK uzun dönem katsayı ve hata düzeltme modeli testlerinin sonuçları; uygulanan eş-bütünleşme testlerinin sonuçlarıyla tutarlı bir şekilde Model 2'nin daha anlamlı olduğu göstermiştir. 
Döviz kuru ile sanayi üretimi arasında kısa dönem ilişkisine rastlanmamasının nedeni; üretim kısa vadede değiştirilemediğinden, yani uzun vadeli bir süreç olduğundan dolayı kurdaki hareketlenmeler sanayi üretimi üzerinde bir çeyrekte etki göstermez. Kurdaki hareketlenmeler, sanayi üretimi üzerindeki etkisi uzun dönemde göstermektedir.

Ayrıca, KUR ve SUE değişkenleri arasında uzun dönem eş-bütünleşme ilişkisi bulunduğundan dolayı, aralarında bir nedensellik ilişkisinin olup olmadığını tespit etmek için nedensellik analizi yapılmıştır. Değişkenler arasında nedensellik analizi yapmak için öncelikle VAR modele uygun gecikme uzunluğu LR, FPE AIC, SC, HQ kriterlerine göre "5" olarak belirlenmiş̧ir. Daha sonra yapılan Toda-Yomamoto yöntemi ile dönüştürülmüş Wald-testi (Granger Nedensellik analizi) sonuçlarına göre; döviz kuru ile sanayi üretimi arasında herhangi bir nedensellik ilişkisine rastlanmamıştır. H0 hipotezleri kabul edilmiş, H1 hipotezleri reddedilmiştir. Bu durum, ekonometrik yöntemlerle uygulanan nedensellik testinin sonucunun anlamsız olduğunu ve analizde kullanılan KUR ve SUE değişkenleri arasında uzun dönemli bir nedensellik etkileşiminin olmadığını göstermektedir.

Çalışmada Türkiye'de döviz kuru ile sanayi üretimi arasındaki ilişki 2005:Q1-2019:Q1 dönemini kapsayan üçer aylık orijinal zaman serileri kullanılarak incelenmiştir. Böylece analizde kullanılan verilerin yıl aralığı ve çeyrek dönemlerin kullanılması itibariyle ve kullanılan farklı zaman serisi yöntemi ile literatüre katkı sağlayacağı düşünülmektedir.

\section{Kaynakça}

Adejumo, A. O., \& Ikhide, S. I. (2019). The Effects of Remittance Inflows on Exchange Rates in Nigeria. Journal of Developing Areas, 53(1), 1-15. https://doi.org/10.1353/jda.2019.0000

Ahmed, F., Owais, M., Kumari, S., \& Rajjani, R. (2018). Exchange Rate Pass-Through to Macroeconomic İndicators Using Vector Auto Regression: Empirical Evidence from Pakistan. Theoretical and Applied Economics, 25(3), 61-76.

Akbaş, Y. E., Zeren, F., \& Özekicioğlu, H. (2013). Türkiye'de Parasal Aktarım Mekanizması: Yapısal Var Analizi. C.Ü. İktisadi ve İdari Bilimler Dergisi, 14(2), 187-198.

Aktaş, C. (2010). Türkiye'de Reel Döviz Kuru ile İhracat ve İthalat Arasındaki İlişkinin Var Tekniğiyle Analizi. ZKÜ Sosyal Bilimler Dergisi, 6(11), 123-140.

Arı, A. (2010). Dalgalanma Korkusu ve Döviz Kuru Geçiş Etkisi. Journal of Yasar University, $17(5), 2832-2841$. 
Barışı, S., \& Demircioğlu, E. (2006). Türkiye'de Döviz Kuru Rejimi, Konvertibilite, İhracatİthalat İlişkisi (1980-2001). ZKÜ Sosyal Bilimler Dergisi, 2(3), 71-84.

Berument, H., \& Pasaogulları, M. (2003). Effects of the Real Exchange Rate on Output and Inflation: Evidence from Turkey. The Developing Economies, 41(4), 401-435.

Bilgin, C., \& Şahbaz, A. (2009). Türkiye'de Büyüme ve İhracat Arasındaki Nedensellik İlişkileri. Gaziantep Üniversitesi Sosyal Bilimler Dergisi, 8(1), 177-198. https://doi.org/10.1111/j.1746-1049.2003.tb01009.x

Bozoklu, Ş., \& Yılancı, V. (2014). Türk Sermaye Piyasasında Fiyat ve İşlem Hacmi İlişkisi: Zamanla Değişen Asimetrik Nedensellik Analizi. Ege Akademik Bakış, 14(2), 211-220. https://doi.org/10.21121/eab.2014218052

Cambazoğlu, B., \& Karaalp, H. S. (2012). Parasal Aktarım Mekanizması Döviz Kuru Kanalı: Türkiye Örneği. Yönetim ve Ekonomi, 19(2), 53-66.

Choudhry, T. (2005). Exchange Rate Volatility and The United States Exports: Evidence from Canada and Japan. Journal of The Japanese and International Economies, 19(1), 51-71. https://doi.org/10.1016/j.jjie.2003.11.002

Cihangir, M., \& Kandemir, T. (2010). Finansal Kriz Dönemlerinde Hisse Senetleri Getirilerini Etkileyen Makroekonomik Faktörlerin Arbitraj Fiyatlandırma Modeli Aracılığıyla Saptanmasına Yönelik Bir Çalışma (Kasım 2000 ve Şubat 2001 Finansal Krizleri Üzerine Değerlendirme ve Gözlemler). Süleyman Demirel Üniversitesi İktisadi ve İdari Bilimler Fakültesi Dergisi, 15(1), 257-296.

Dickey, David A., ve Wayne A. FULLER. 1981. "Likelihood Ratio Statistics for Autoregressive Time Series with a Unit Root”. Econometrica 49 (4): 1057-72. https://doi.org/10.2307/1912517.

Dickey, D. A., W. A.r FULLER. 1979. "Distribution of the Estimators for Autoregressive Time Series with a Unit Root”. Journal of American Statistical Association 74 (366).

Duman, Y. K., \& Sağdıç, A. (2019). Türkiye'de Döviz Kuru ve Enflasyon İlişkisi: Ekonometrik Bir Analiz (2003:1-2017:3). Sakarya İktisat Dergisi, 8(1), 1-16.

Ecevit, E., \& Çetin, M. (2016). Ekonomik Büyüme ve Çevre Kirliliğinin Sağlık Üzerindeki Etkisi: Türkiye İle İlgili Ampirik Kanıt. Erciyes Üniversitesi İktisadi ve İdari Bilimler Fakültesi Dergisi, (48), 83-98.

Edwards, S. (2006). The Relationship Between Exchange Rates and Inflation Targeting Revisited. Central Bank of Chile Working Papers, 409, 41. https://doi.org/10.3386/w12163

Engle, R. and Granger, C. (1987) Cointegration and Error Correction: Representation, Estimation and Testing. Econometrica, 55, 251-276. 
Ghorbani, M., \& Motallebi, M. (2009). Application Pesaran and Shin Method for Estimating Irans Import Demand Function. Journal of Applied Sciences, 9(6), 1175-1179.

Gül, E., \& Ekinci, A. (2006). Türkiye'de Reel Döviz Kuru ile İhracat ve İthalat Arasındaki Nedensellik İlişkisi: 1990-2006. Dumlupınar Üniversitesi Sosyal Bilimler Dergisi, (16).

Hooper, P., \& Mann, C. L. (1989). Exchange Rate Pass-Through in the 1980s: The Case of U.S. Imports of Manufactures. Brookings Papers on Economic Activity, (1), 297-337. https://doi.org/10.2307/2534500

Kasman, A., \& Kasman, S. (2005). Exchange Rate Uncertainty in Turkey and Its Impact on Export Volume. METU Studies in Development, 32(June), 41-58.

Kızıltan, A., \& Ciğerlioğlu, O. (2008). Türkiye'de Reel Döviz Kuru Değişmelerinin İhracat ve İthalata Etkisi. Ekev Akademi Dergisi, 12(36), 423-444.

Krugman, P. R., Obstfeld, M., \& Melitz, M. J. (2012). International Economics: Theory \& Policy (9th ed). Boston: Pearson Addison-Wesley

O.Awokuse, T. (2002). Is The Export-Lead Growth Hypothesis Valid for Canada? Department of Food and Resource Economics, University of Delaware, 25.

Phillips, P. and Ouliaris, S. (1988) Testing for cointegration using principal components methods. Journa! 01 Economic Dynamics and Control 12, 205-230.

Šimáková, J. (2018). Asymmetric Effects of Exchange Rate Changes on The Foreign Trade of Czechia. Eastern European Economics, 56(5), 422-437. https://doi.org/10.1080/00128775.2018.1487767

Singh, G. (2016). The Impact of Macroeconomic Fundamentals on Stock Prices Revised: A Study of Indian Stock Market. Journal of International Economics, 7(1), 76-91.

Şentürk, M., \& Akbaş, Y. E. (2014). İşsizlik-Enflasyon ve Ekonomik Büyüme Arasındaki Karşılıklı İlişkinin Değerlendirilmesi: Türkiye Örneği. Journal of Yasar University, 9(34), 5820-5832. https://doi.org/10.19168/jyu.43548

Toda, H. Y. and Yamamoto T. (1995), Statistical Inferences In Vector Autoregressions With Possibly Integrated Processes. Journal of Econometrics, 66, p.225-25

Uğur, A., Sancar, C., \& Atay Polat, M. (2016). Türkiye'de Parasal Aktarım Mekanizması Kanallarının İşleyişine İlişkin Ampirik Bulgular: (1998-2015). International Journal of Eurasia Social Sciences, 7(22), 34-55.

Yıldırım, E., \& Kesikoğlu, F. (2012). İthalat-İhracat-Döviz Kuru Bağımlılı̆̆ı: Bootstrap ile Düzeltilmiş Nedensellik Testi Uygulaması. Ege Akademik Bakış, 12(2), 137 